\title{
PERLINDUNGAN HUKUM BAGI KONSUMEN TERHADAP IKLAN YANG MENYEBABKAN KEKELIRUAN
}

\author{
Angel Amalia ${ }^{1}$, Margo Hadi Pura ${ }^{2}$ \\ ${ }^{1}$ Fakultas Hukum, Universitas Singaperbangsa Karawang, angelamalia283@gmail.com \\ ${ }^{2}$ Fakultas Hukum, Universitas Singaperbangsa Karawang
}

\section{ABSTRACT}

This study aims to see how legal protection for consumers for the existence of advertisements that causes mistakes and the for responsibility given by business actors. The existence of misleding or inappropriate advertisements is detrimental to consumers, causing problems between consumer who demand their rights from business actors who advertise their products. The problem raised is about how the legal protection for consumers related to misleading advertisements in the perspective of consumer protection and how the responsibility of business actors to consumers related to advertisements that cause errors. This study uses a normative juridical method, which is studied by means of an invitation. With the existence of Law Number 8 of 1999 concering Consumer Protection (UUPK) and the Indonesian Advertising Code of Ethics for consumers who are disadvantaged by business actors over advertisements that cause errors, they can obtain protection from business actor fraud. In addition, advertising business actors must be responsible in accordance with Article 20 of the UUPK.

\section{ARTICLE INFO}

\section{Keywords:}

consumers; advertisements that cause errors; business actors

\section{Cite this paper:}

Angel Amalia, M. H. (2021). Perlindungan Hukum Bagi Konsumen Terhadap Iklan Yang Menyebabkan Kekeliruan. Widya Yuridika: Jurnal Hukum, $4(2)$.

\section{Scope Article}

Human Rights

\section{PENDAHULUAN}

Pembangunan dan perkembangan perekonomian khususnya dibidang perindustrian dan perdagangan nasional telah menghasilkan berbagai variasi barang dan/atau jasa yang dapat dikonsumsi ${ }^{1}$.Oleh karena banyak nya variasi barang dan/ atau jasa ini, maka berbagai pelaku usaha berlomba-lomba untuk menawarkan produknya agar produk yang diproduksi dapat diminati oleh masyarakat luas.

Salah satu alat yang sering digunakan pelaku usaha untuk memasarkan produkproduknya adalah dengan Iklan. Menurut Undang-Undang Nomor 8 tahun 1999 tentang Perlindungan Konsumen, promosi adalah kegiatan pengenalan atau penyebarluasan informasi suatu barang dan/atau jasa, untuk menarik minat beli konsumen terhadap barang dan/atau jasa yang akan dan sedang diperdagangkan. ${ }^{2}$

\footnotetext{
${ }^{1}$ Zulkarnaen, Perlindungan Hukum Terhadap Konsumen Barang-Barang Elektronik, Tesis pada Program Magister Ilmu Hukum Universitas Diponegoro, Semarang, 2008

2 Pasal 1 angka 6 Undang-undang Nomor 8 Tahun 1999 Tentang Perlindungan Konsumen.
} 
Iklan merupakan salah satu sarana pemasaran yang sangat banyak dipergunakan oleh pelaku usaha untuk memperkenalkan aneka produk yang dihasilkan kepada konsumen, serta untuk meningkatkan kesadaran konsumen terhadap aneka produk yang dihasilkan. ${ }^{3}$

Pentingnya media iklan bagi pelaku usaha dapat tergambar dalam pendapatyang disampaikan oleh David Oughnton dan John Lowry, yang menulis bahwa

"Advertising is the central symbol of consumer society, advertising plays a central role in making avaible to consumers information which the producers of the advertised product wishes the consumer to have "4

Periklanan adalah simbol utama dari masyarakat konsumen, iklan memainkan peran penting dalam membuat tersedia informasi untuk konsumen dimana pelaku usaha yang mengiklankan produk berharap konsumen untuk memiliki). Melalui iklan, pelaku usaha seharusnya dapat lebih mendekatkan diri kepada konsumen, dengan menghasilkan beraneka produk yang sesuai dengan keingginan dan kebutuhan konsumen. ${ }^{5}$

Persaingan bisnis yang semakin tajam telah memicu munculnya berbagai jenis dan model periklanan yang terkadang jauh dari nilai-nilai etika dan nilai-nilai kebenaran. Karena strategi ini harus dilakukan agar konsumen mau membeli produk yang ditawarkan, maka iklan yang ditampilkan seringkali terlihat memberikan kesan dan pesan yang berlebihan, dan tidak jarang mengabaikan norma-norma dan nilai-nilai etika, sebagai akibatnya iklaniklan tersebut sering menimbulkan citra bisnis yang negatif, bahkan dianggap menipu 6 .

Ketentuan mengenai periklanan secara umum telah ada, namun pada kenyataannya masih banyak terdapat pelanggaran-pelanggaran yang telah dilakukan oleh pelaku usaha yang merugikan konsumen. Permasalahan ini menempatkan konsumen pada posisi sangat lemah karena sulitnya dalam pembuktian dan tidak terlibatnya konsumen dalam proses pembuatan hingga akhir sebuah produk. Lemahnya posisi konsumen ini mengakibatkan konsumen kesusahan dalam menuntut haknya kepada pelaku usaha. ${ }^{7}$

Konsumen perlu diberikan suatu perlindungan khusus terhadap informasi iklan barang dan jasa yang menyebabkan kekeliruan. Perlunya peraturan yang mengatur perlindungan konsumen karena lemahnya posisi konsumen dibandingkan posisi pelaku usaha, karena mengenai proses sampai hasil produksi barang atau jasa yang telah dihasilkan tanpa campur tangan konsumen sedikitpun sehingga kenyataannya konsumen selalu berada dalam posisi yang dirugikan. Campur tangan negara sendiri dimaksudkan untuk melindungi hak-hak konsumen.

Sementara itu, Janus Sidabalok mengemukakan ada empat alasan pokok mengapa konsumen perlu dilindungi, yaitu sebagai berikut :

1. Melindungi konsumen sama artinya dengan melindungi seluruh bangsa sebagaimana diamanatkan oleh tujuan pembangunan nasional menurut Undang-Undang Dasar 1945;

2. Melindungi konsumen perlu untuk menghindarkan konsumen dari dampak negatif penggunaan teknologi;

3. Melindungi konsumen perlu untuk melahirkan manusia-manusia yang sehat rohani dan jasmani sebagai pelaku-pelaku pembangunan, yang berarti juga untuk menjaga kesinambungan pambangunan nasional;

4. Melindungi konsumen perlu untuk menjamin sumber dana pembangunan yang bersumber dari masyarakat konsumen.

Namun demikian, realitas yang terjadi dimasyarakat tidak selamanya berjalan sebagaimana yang diharapkan. Sering kali ditemukan pelaku usaha menyampaikan

\footnotetext{
${ }^{3}$ Dedi Harianto, Perlindungan Hukum Bagi Konsumen Terhadap Iklan Yang Menyesatkan, Bogor, Ghalia Indonesia, 2010, hlm. 3

${ }^{4}$ Ibid hlm 4

${ }^{5}$ Adi Handono, Perlindungan Hukum Bagi Konsumen Terhadap Informasi Iklan Barang Dan Jasa Yang Menyesatkan, Tesis pada Program Magister Ilmu Hukum Universitas Jember, Jember, 2011

${ }^{6}$ Mabarroh Azizah, 2013, Etika Perilaku Periklanan Dalam Bisnis Islam, Jurnal Ekonomi Syariah Indonesia vol III, No 1 Juni 2013/1434 H, HIm. 38

${ }^{7}$ Husni Ayawali, Neni Sri Imaniyati (ed), Hukum Perlindungan Konsumen, Mandar Maju, Bandung, 2000, hlm. 7
} 
informasi yang menyebabkan kekeliruan melalui iklan. Hal tersebut dapat dibuktikan dari hasil data Badan Pengawas Periklanan Persatuan Perusahaan Periklanan Indonesia (PPPI). Berdasar data Badan Pengawas Periklanan (BPP) PPPI periode 2005-2008, ditemukan 346 iklan bermasalah. Sekitar 277 iklan di antaranya dinyatakan melanggar etika pariwara periklanan. Kebanyakan pelanggaran tersebut terkait dengan penggunaan istilah atau kata yang bersifat superlatif tanpa bukti pendukung yang objektif. Hingga Oktober 2009, ditemukan 150 kasus iklan bermasalah ${ }^{8}$. Berdasarkan hal tersebut Penulis terdorong untuk membuat penelitian yang berjudul "Perlindungan Hukum Konsumen Terhadap Iklan Yang Menyebabkan Kekeliruan “

\section{METODE}

Metode pendekatan yang digunakan dalam penelitian ini adalah pendekatan hukum normative yaitu menemukan kebenaran berdasarkan logika keilmuan hukum dari sisi normatif melalui peraturan perundang - undangan yang mengkaji norma dalam hal konten dalam iklan yang mengandung unsur penyesatan atau hal negatif dan berbasis ilmu hukum. Jenis penelitian yang digunakan adalah deskriptif berupa kata-kata tertulis atau lisan, gambar, dan content dari sebuah iklan yang terdapat dalam facebook twitter dan instagram dibandingkan dengan sebuah norma konsep hukum yang terdapat dalam undang - undang mengenai iklan yang terdapat dalam iklan pada media sosial Facebook Twitter dan Instagram. Tujuannya untuk memberikan gambaran seteliti mungkin secara sistematis dan menyeluruh tentang kebijakan penerapan peraturan yang ada dalam perlindungan konsumen. ${ }^{9}$

\section{HASIL DAN PEMBAHASAN}

\section{Unsur-Unsur Standar Penentuan Informasi Iklan Serta Pertangungjawabannya}

Iklan adalah segala bentuk promosi yang ditujukan untuk memperbesar penjualan barang dan jasa dari pemberi pesan kepada masyarakat dengan mempergunakan media yang dibayar berdasarkan tarif tertentu. Aspek peningkatan penjualan barang dan / jasa menjadi tujuan utama pelaku usaha untuk beriklan, ${ }^{10}$ sehingga pelaku usaha berupaya seoptimal mungkin memanfaatkan media iklan untuk menggali sisi komsumtif konsumen dengan berbagai barang atau jasa yang belum tentu jelas manfaatnya bagi konsumen. salah satu ketentuan yang memuat peraturan periklanan, yaitu peraturan pemerintah (PP) no 69 tahun 1999 tentang label dan iklan pangan, ini menekankan aspek penyebaran / pemberian informasi produksi kepada konsumen, sehingga iklan bukan hanya semata menjadi sarana promosi tetapi juga untuk konsumen memperoleh informasi produk yang sesuai dengan kebutuhan.

Yurispridensi di Indonesia, belum memberikan batasan secara tegas mengenai apa yang dimaksud dengan iklan. Tetapi , dalam putusan Mahkamah Agung tanggal 5 juli 1972 no. 27 K/SIP/1972, dalam kasus iklan memuat unsur-unsur sebagai berikut: ${ }^{11}$
a. Pengumuman
b. Memuat kata-kata dengan tentang format
c. Untuk (mengejar) suatu maksud atau tujuan
d. Tentang patokan (Tidak melampaui) batasan-batasan dari yang diperlukan

Dalam kegiatan perikalan terlihat adanya beberapa unsur, yaitu sebagai berikut :

\footnotetext{
${ }^{8}$ http://www.iklankoran.net/PPPI_Temukan_150_Iklan_Bermasalah.html Terakhir diakses 10 Oktober 2019

${ }^{9}$ Wahyu Aji Chalifar, 2018, Konsumen Dan Iklan : Studi Tentang Iklan Yang Menyesatkan Di Facebook Twitter Dan Instagram, Surakarta,HIm 3

${ }^{10}$ UU No 8 tahun 1999 tentang perlindungan konsumen dibedakan antara pelaku usaha sebagaimana terdapat dalam pasal 1 angka 3 UU no 8 tahun 1999 tentang perlindungan konsumen

${ }^{11}$ S.P.de Boer v.N.V.Good Year Sumatra Plantations Ltd. Cs., Putusan Mahkamah Agung No. 27 K/SIP/1972,tanggal 5 juli 1972
} 
1. Produsen, yaitu pemimpin perusahaan atau pengusaha yang memproduksi suatu produk

2. Konsumen, yaitu pemakai/pembeli suatu produk

3. Produk (barang atau jasa) yang diproduksi dan dianjurkan pada konsumen agar mau membelinya

4. Message, yaitu pesan-pesan anjuran tentang suatu produk kepada konsumen

5. Media iklan, yaitu tempat atau waktu yang disewa untuk mempromosikan suatu produk kepada konsumen.

6. Efek, yaitu perubahan tingkah laku konsumen, dimana ia menerima anjuran pesan-pesan iklan yang mengakibatkan ia membeli produk

Sebagai salah satu bentuk kegiatan promosi, iklan diketahui mempunyai keberagaman jenis yang cukup kompleks sesuai dengan khalayak yang ditujukan oleh iklan tersebut, bebrapa jenis diantaranya adalah iklan merek (brand adversiting) , iklan local atau eceran (retail or local advertising), iklan politik (political advertising), iklan petunjuk (directory advertising), iklan tanggapan langsung (direct-response advertising), iklan untuk kalangan bisnis (business-to-bussiness advertising), iklan kelembagaan (institutional advertising), iklan layanan masyarakat (public service advertising), iklan interaktif (interactive advetising). Dan variasi lain jenis- jenis iklan yang berkembang dalam kegiatan periklan adalah seperti berikut iklan pancingan (bait and switch advertising), iklan perbandingan (comparative advertising), iklan perbaikan (corrective advertising).

Idealnya, seluruh media komunikasi pemasaran yang dipergunakan oelaku usaha dapat memberikan informasi secara benar, jujur, dan tidak menipu apalagi menyebabkan kekeliruan konsumen, dengan mengidahkan apa yang sering disebut bussines ethics, yaitu fairness and honesty to the public, the consumers, competitors, and to the government. Tetapi, persaingan usaha yang sangat keras dan tidak meratanya kemampuan di antara para pelaku usaha, sering kali menempatkan pelaku usaha dalam pilihan yang sulit, termasuk melakukan praktik bisnis yang tidak jujur (unfair trade paractice). Dalam bisnis yang sehat, praktik-praktik bisnis yang tidak jujur (unfair trade practice) sangat dilarang.

Misalnya

a. Perbuatan yang bersifat bohong atau menyebabkan kekeliruan

b. Pernyataan menyebabkan kekeliruan mengenai sifat,ciri,standar, atau mutu suatu barang

c. Pernyataan bohong dalam pemberian hadiah atau potongan harga

d. Iklan bohong

e. Penjualan produk yang disertai janji potongan harga apabbila pembeli membawa serta calon pembeli lainnya kepada penjual

f. Penjualan produk yang tidak memenuhi standar keselamatan konsumen

g. Penjualan produk yang tidak memenuhi standar keselamatan konsumen

h. Penjualan produk yang tidak memenuhi standar informasi konsumen

Mencermati kelemahan-kelamahan dalam pengaturan kegiatan periklanan dan praktik pengawasan informasi iklan' maka dipandang perlu untuk memberikan penegasan mengenai keberadaan fakta material dan konsumen rasional sebagai standar penentuan iklan menyebabkan kekeliruan di Indonesia. Selain standar penentuan informasi iklan yang terdapat dalam berbagai peraturan perundang-undangan baik di tingkat federal maupun Negara bagian, serta dalam kode etik periklanan, di amerika 
serikat standar penentuan informasi iklan juga telah di tetapkan federal trade commission (FTC) maupun pengadilan dalam menangani berbagai kasus periklanan.

\section{Pertanggungjawaban Serta Perlindungan Terhadap Konsumen Yang Telah Dirugikan Oleh Iklan Yang Menyebabkan Kekeliruan}

Seperti yang kita ketahui dalam berita online detiknews.com yang dilansir pada tanggal 4 Juli 2018, dalam berita tersebut BPOM telah mengeluarkan Surat Edaran Nomor HK. 06.5.51.511.05.18.2000 tahun 2018 tentang "Label dan Iklan pada Produk Susu Kental dan Analognya” yang berisi 4 (empat) larangan terkait mengkonsumi susu kental manis yakni :

- Dilarang menampilkan anak-anak berusia di bawah 5 tahun dalam bentuk apapun.

- Dilarang menggunakan visualisasi bahwa produ susu kental dan analognya (Kategori Pangan 01.03) disetarakan dengan produk susu lainnya sebagai penambah atau pelengkap zat gizi. Produk susu lain antara lain susu sapi/susu yang dipasteurisasi/susu yang disterilisasi/susu formula/susu pertumbuhan

- Dilarang menggunakan visualisasi gambar susu cair dan/atau susu dalam gelas serta disajikan dengan cara diseduh untuk dikonsumsi sebagai minuman.

- Khusus untuk iklan, dilarang ditayangkan pada jam tayang acara anak-anak. ${ }^{12}$

Dari pemaparan Surat Edaran dari BPOM tersebut dan apabila dikaji dalam Hukum Perlindungan konsumen, maka patut kemudian perusahaaan susu kental manis harus dimintai pertanggungjawaban secara hukum. Berikut akan kita bahas bagaimana pertanggungjawaban serta perlindungan terhadap konsumen yang dirugikan oleh iklan yang menyebabkan kekeliruan.

Apabila iklan berpotensi menimbulkan kerugian kepada konsumen, maka harus dipertimbangkan kemungkinan terdapatnya peluang untuk meminta pertanggungjawaban para pihak yang terlibat dalam kegiatan periklanan, terutama pelanggaran-pelanggaran terhadap ketentuan yang terdapat dalam UUPK, peraturan pemerintah, serta berbagai peraturan yang bersifat administrative, misalnya dalam surat keputusan menteri kesehatan, maupun BPOM. Secara garis besar, pertanggung jawaban itu sendiri muncul terkait dengan 2 hal yaitu: ${ }^{13}$

- Informasi produk yang disajikan memalui iklan tidak sesuai dengan kenyataan yang sebenanya

- Menyangkut kreativitas perusahaan periklanan dan/atau media periklanan ternyata bertentangan dengan asas-asas etik periklanan

Mengenai muatan informasi produk, tentu pihak yang paling bertanggungjawab adalah pengiklan sebagai pihak penghasil barang atau jasa. Sedangkan yang menyangkut daya kreativitas dalam pembuatan iklan, tentu merupakan tanggungjawab perusahaan periklanan dan media ilan, karena berdasar daya imajinasi mereka iklan dapat tampil lebih memikat dan mampu mengundang perhatian konsumen. ${ }^{14}$

Dalam UUPK, memungkinakan untuk menerima pertanggungjawaban para pihak pada kegiatan periklanan telah disesuaikan dengan dua kemungkinan tersebut. Misalnya, bagi pengiklan dimungkinkan berdasar ketentuan dalam pasal 19 ayat (1) UUPK, sebagai berikut :

\footnotetext{
12 https://news.detik.com/berita/4098935/heboh-kental-manis Terakhir diakses 10 Oktober 2019

13 Yusuf shofie,4,"system tanggung jawab dalam periklanan", hukum dan pembangunan,no.2 tahun xxvi,april 1996,hal.142.

${ }^{14}$ Badan pembinaan hukum nasional,1,op.cit.,hal 12
} 
"pelaku usaha bertanggungjawab memberikan ganti rugi atas kerusakan, pencemaran dan / atau kerugian konsumen akibat mengkonsumsi barang dan / atau jasa yang dihasilkan atau di perdangangkan."

Bagi perusahaan periklanan atau media iklan, keharusan untuk bertangunggjawab dimuat dalam pasal 20 UU No 8 tahun 1999 tentang perlindungan konsumen, bahwa pelaku usaha periklanan bertangungjawab atas iklan yang di produksi dan segala akibat yang ditimbulkan oleh iklan tersebut.

Dalam pasal 45 ayat (2) PP 69 tahun 1999 tentang label dan iklan pangan, telah terperinci lagi para pihak yang turut bertangungjawab terhadap tindakan penyesatan dalam iklan meliputi :

“ penerbit, pencetak, pemengang izin siara radio atau televisi, agen dan atau media

yang di pergunakan untuk menyebarkan iklan, turut bertangungjawab terhadap isi iklan yang tidak benar, kecuali yang bersangkutan telah mengambil tindakan yang diperlukan untuk meneliti kebenaran isi iklan yang bersangkutan."

Upaya untuk meminta pertanggungjawaban para pihak dalam kegiatan periklanan, bukannlah persoalan yang mudah dilaksanakan. Oleh, karena itu pertanggungjawaban didasarkan dua pertimbangan, yaitu:

a. Kegiatan periklanan melibatkan banyak pelaku ekonomi, dalam hal ini pengusaha pengiklan (produsen, distributor, supplier, retailer), pengusaha,periklanan, organisasi profesi periklanan, dan media periklanan. Di samping itu, juga melibatkan konsumen selaku penerima informasi yang disajikan memalui iklan, dan pemerintah dalam hal ini departemen komunikasi dan informasi, departemen kesehatan, dan departemen perdagangan. ${ }^{15}$

b. Tempat periklanan sendiri dalam pembidangan hukum di Indonesia lebih banyak di kelompokan dalam bidang hukum administrasi Negara, khususnya kelompok hukum pers. ${ }^{16}$

Tentunya dituntut keluwesan dan kebijaksanaan aparat pemerintah serta aparat penegak hukum dalam menerapkan ketentuan-ketentuan yang mengatur kegiatan periklananan, sehingga kendala keterbatasan pengaturan tidak menjadi penghalang untuk meminta pertanggungjawaban pelaku usaha periklanan.

Dalam aktivitas periklanan, terdapat setidaknya beberapa pihak yang terlibat dalam kegiatan periklanan dalam menjalankan fungsinya masing-masing antara lain: ${ }^{17}$

a. Pengiklan, yaitu badan usaha yang memesan iklan dan membayar biaya pembuatannya untuk promosi/pemasaran produknya dengan menyampaikan pesan-pesan dan berbagai informasi lainnya tentang produk tersebut kepada perusahaan iklan;

b. Perusahaan periklanan, yaitu perusahaan atau biro iklan yang merancang, membuat atau menciptakan iklan berdasrkan pesan atau informasi yang disampaikan pengiklan kepadanya;

\footnotetext{
${ }^{15}$ Yusuf shofie 1 op.cit., hal 148

${ }^{16}$ A.z nasution,4,kedudukan hukum konsumen terhadap iklan, makalah yang disampaikan pada seminar hukum "perlindungan hukum bagi konsumen dari dampak iklan", di selenggarakan senat mahasiswa fakultas hukum universitas isalam as syafi'iyah, Jakarta, 6 mei 1995, hal 12.

${ }^{17}$ A.z nasution,1, op.cit., hal 148
} 
c. Media periklanan, yaitu media non elektronik (Koran, majalah, dan seterusnya) atau media elektronik (seperti radio, televise, seterusnya) yang digunakan untuk menyiarkan dan/ atau menayangkan iklan-iklan tertentu.

Dalam upayanya dalam memperkenalkan produk kepada konsumen, pengiklan dapat melakukan beberapa upaya, salah satu di antaranya adalah pengiklan akan menghubungi perusahaan pengiklan untuk menuangkan berbagai informasi produk tersebut dalam suatu konsep iklan yang dapat menarik perhatian konsumen, sekaligus dapat memenuhi keingintahuan konsumen terhadap informasi produk yang diiklankan.

Memperhatikan proses pembuatan sebuah iklan, maka akan terlihat bahwa perusahaan periklanan dalam menjalankan kegiatannya terikat oleh hubungan hukum tertentu dalam sebuah kontrak keagenan (agency contract). Hubungan ini merupakan salah satu bentuk hubungan hukum sebagaimana diatur dalam pasal $1610 \mathrm{KUH}$ Perdata mengenai perjanjian-perjanjian untuk melakukan sementara jasa-jasa yang bukan hubungan kerja (majikan-buruh) maupun persetujuan dalam rangka pemborongan pekerjaan.

Peraturan mengenai kewajiban media iklan untuk melakukan mekanisme control di tentukan dalam beberapa pasal dari beberapa peraturan yang berbeda, diantaranya pasal 6 UU No. 40 Tahun 1999 tentang Pers, ditegaskan seperti berikut ini :

a. Memenuhi hak masyarakat untuk mengetahui

b. Menegakkan nilai nilai dasar demokrasi, mendorong terwujudnya supremasi hukum, dan hak asasi manusia, serta menghormati kebhinekaan.

c. Mengembangkan pendapat umum berdasarkan informasi yang tepat, akurat dan benar.

d. Melakukan pengawasan, kritik, koreksi dan saran terhadap hal-hal yang berkaitan dengan kepentingan umum

e. Memperjuangkan keadilan dan kebenaran

Diberlakukannya UU Pers terhadap perusahaan periklanan di sebabkan perusahaan periklanan termasuk dalam kategori perusahaan pers, ${ }^{18}$ dimana tugas pembinaan dan pengawasannya dilaksanakan oleh Depkominfo.

Lembaga penyiaran memiliki kewajiban untuk melakukan pengawasan dan koreksi informasi iklan. Hal ini dapat ditemukan di antaranya dalam pasal 26 ayat (2) UU No. 32 tahun 2002 tentang penyiaran yang di tegaskan bahwa dalam menyelenggarakan siarannya, lembaga penyiaran berlanggaran harus:

a. Melakukan sensor internal terhadap semua isi siaran yang akan disiarkan dan/ atau disalurkan

b. Menyediakan sekurang-kurangnya $10 \%$ (sepuluh persen) dari kapasitas kanal saluran untuk menyalurkan program dari lembaga penyiaran public dan lembaga penyiaran swasta

c. Menyediakan 1\% kanal saluran siaran produksi dalam negeri berbanding 10 siaran produksi luar negeri sekurnag-kurangnya 1 kanal saluran siaran produksi dalam negeri.

Selain melakukan koreksi, dalam rancangan undang-undang periklanan bab iv perusahaan periklanan, ayat (1) ditegaskan bahwa perusahaan periklanan berkewajban

18 Pasal 13 uu no 40 tahun 1999 tentang pers (lembaga Negara republik Indonesia no.166 tahun 1999) 
mengingatkan pengiklan tentang hal-hal yang bertentangan dengan hukum dan atau kode etik periklanan. Selanjutnya, dalam ayat (2) ditambahkan bahwa perusahaan periklanan yang telah menjalankan kewajiban dapat membebaskan diri dari gugatan dan tuntutan.

Dalam kegiatan periklanan, tanggung jawab pelaku usaha periklanan dapat timbul sebagai akibat pelanggaran terhadap larangan-larangan dalam UUPK sebagaimana diatur dalam pasal 9, pasal 10, pasal 12 dan pasal 13, yang berhubungan dengan berbagai macam larangan dalam melakukan penawaran, promosi, maupun mengiklankan barang dan atau jasa, serta ketentuan pasal 17 UUPK yang khusus di peruntukkan bagi perusahaan periklanan. Disamping itu. Pelanggrana juga dapat dilakukan terhadap larangan-larangan dalam berbagai peraturan perundang-undangan lain seperti KUH perdata, KUHP, peraturan pemerintah (PP), peraturan yang bersifat administrative, misalnya keputusan menteri, serta etika pariwara Indonesia (EPI) .

Melihat keberagaman pengaturan kegiatan periklanan tersebut, maka pertanggungjawaban pelaku usaha periklanan dapat pula di klasifikasikan menjadi beberapa bentuk pertanggungjawaban, yaitu secara perdata, pidana, dan administrasi Negara, sesuai dengan jenis pelanggaran dan pasal-pasal yang dituduhkan kepada pelaku usaha periklanan. Sebagaimana tergambar dalam pemaparan singkat berikut :

a. Tanggung jawab perdata terhadap iklan menyebabkan kekeliruan Kewajiban para pihak dalam kegiatan periklanan untuk bertanggungjawab secara perdata dapat muncul didasar pertanggungjawabnan kontraktual (contractual liability) maupun berdasarkan pertanggungjawaban produk (product liability), serta pertanggungjawaban professional (professional liability). Pemanfaatan ketiga bentuk pertanggungjawaban tersebut disesuaikan dengan pihak yang akan dimintakan pertanggungjawabannya serta melihat ketersediaan kontrak sebagai dasar pengajuan tuntutan.

b. Pertanggungjawaban Pidana Pelaku Usaha Periklanan

Untuk menimbulkan efek jera bagi para pelaku pelanggran ketentuan periklanan, maka dimungkinkan untuk mengenakan sanksi pidana pula di samping pengajuan pertanggungjawaban secara perdata. Hal ini dengan tegas dinyatakan dalam pasal 19 ayat 3 UU no 8 tahun 1999 Tentang Perlindungan Konsumen, bahwa pemberian ganti rugi sebagaimana dimaksud dalam ayat (1) dan ayat (2) tidak menghapuskan kemungkinan adanya tuntutan pidana berdasarkan pembuktian lebih lanjut mengenai adanya unsur kesalahan.

c. Pertanggungjawaban Administrasi Negara Pelaku Usaha Periklanan

Dalam rangka pertanggungjawaban secara administrasi Negara, pemahaman masyarakat pada umumnya tertuju kepada sanksi- sanksi berupa penghentian kegiatan untuk sementara, pencabutan izin usaha dan sebagainya, sebagai tindak lanjut dari kewenangan pemerintah dalam mengatur, menata, dan mengendalikan, berbagai kegiatan dalam kehidupan masyarakat, termasuk di antaranya membuat peraturan perundang-undangan, pemberian izin atau lisensi, mengadakan perencanaan dan subsidi. Oleh karena itu, pengenaan sanksi administrative dapat ditemukan pada berbagai peraturan perundang-undangan yang mengatur berbagai kegiatan dalam kehidupan masyarakat.

Terdapat kemungkinan bagi konsumen dalam mengkonsumsi barang dan/ atau jasa akan menghadapi masalah, apalagi dengan mengingat bahwa pada umumnya produk yang ditawarkan pelaku usaha di produksi dalam jumlah sangat banyak (massal), sehingga tidak terhindarkan dari kemungkinan cacat produk. Untuk itu, harus disediakan suatu mekanisme penyelesaian konsumen yang mampu menampung dan dan menyelesaikan seluruh permasalahan konsumen tersebut, sebagai realisasi dari salah 
satu hak konsumen yang diberikan jaminan dalam UUPK, yaitu: "hak untuk mendapatkan advokasi, perlindungan, dan upaya penyelesaian sengketa perlindungan konsumen secara patut."

Menurut resolusi majelis umum perserikatan bangsa-bangsa no. A./ RES/39/248, tanggal 16 april 1985 tentang pedoman perlindungan konsumen (guidelines for consumer protection), terdapat tiga agenda yang harus ditindaklanjuti pemerintah, masing-masing Negara berkaitan dengan penyelesaian sengketa kosumen, yaitu;

1. Pemerintah harus menetapkan perangkat-perangkat hukum memungkinkan konsumen atau organisasi-organisasi terkait lainnya untuk memperoleh penyelesaian melalui prosedur-prosedur formal dan informal (ekpenditious), adil (fair), murah (inexpensive), dan terjangkau (accessible) untuk menampung terutama kebutuhan-kebutuhan konsumen berpenghasilan rendah (the needs of low income consumers)

2. Pemerintah harus mendorong semua pelaku usaha (enterprises) untuk menyelesaikan sengketa-sengketa konsumen secara adil, murah dan informal, serta menetapkan mekanisme sukarela (voluntary mechanism), termaksuk jasa konsultasi (advirsory services) dan prosedur penyelesaian informal (informal complaints procedures) yang dapat membantu konsumen

3. Tersedianya infomasi penyesaian ganti rugi dan prosedur penyelesaian sengketa lainnya bagi konsumen

Kebutuhan akan lembaga yang khusus menyelesaikan sengketa konsumen perlu di kembangkan, mengingat pada umumnya konsumen di Negara-negara berkembang enggan ber acara di pengadilan, karena tidak seimbangnya tuntutan kerugian dengan biaya, waktu dan energi yang harus di keluarkan dan terutama karena posisi konsumen yang secara sosial dan finansial tidak sebanding dengan pelaku usaha. Selain itu, sengketa di antara konsumen dan pelaku usaha biasanya nominalnya kecil atau nilai rupiahnya kecil, sehingga tidak terlalu cocok jika harus diselesaikan melalui pengadilan. Dalam kaitannya dengan penyelesaian sengketan konsumen periklanan, maka selain dapat diselesaikan secara perdamaian dengan memanfaatkan bantuan YLKI maupun badan di bahwa naungan asosiasi periklanan, maka dapat pula diajukan kepada BPSK atau peradilan di laingkungan peradilan umum.

1. Penyelesaian sengketa melalui badan penyelesaikan sengketa konsumen

2. Penyesaian sengketa konsumen melalui pengadilan negeri

3. Gugatan class action konsumen periklanan

4. Gugatan legal standing konsumen periklanan

\section{PENUTUP}

Ketentuan mengenai periklanan secara umum telah ada, namun pada kenyataannya masih banyak terdapat pelanggaran-pelanggaran yang telah dilakukan oleh pelaku usaha yang merugikan konsumen. dalam putusan Mahkamah Agung tanggal 5 juli 1972 no. 27 K/SIP/1972, dalam kasus iklan memuat unsur-unsur sebagai berikut : ${ }^{19}$
a. Pengumuman
b. Memuat kata-kata dengan tentang format
c. Untuk (mengejar) suatu maksud atau tujuan
d. Tentang patokan (Tidak melampaui) batasan-batasan dari yang diperlukan
Dalam kegiatan perikalan terlihat adanya beberapa unsur, yaitu sebagai berikut.

\footnotetext{
${ }^{19}$ S.P.de Boer v.N.V.Good Year Sumatra Plantations Ltd. Cs., Putusan Mahkamah Agung No. 27 K/SIP/1972,tanggal 5 juli 1972
} 
1) Produsen, yaitu pemimpin perusahaan atau pengusaha yang memproduksi suatu produk

2) Konsumen, yaitu pemakai/pembeli suatu produk

3) Produk (barang atau jasa) yang diproduksi dan dianjurkan pada konsumen agar mau membelinya

4) Message, yaitu pesan-pesan anjuran tentang suatu produk kepada konsumen

5) Media iklan, yaitu tempat atau waktu yang disewa untuk mempromosikan suatu produk kepada konsumen.

6) Efek, yaitu perubahan tingkah laku konsumen, dimana ia menerima anjuran pesanpesan iklan yang mengakibatkan ia membeli produk

Lahirnya Undang-Undang Perlindungan Konsumen membawa era baru dalam upaya memberikan perlindungan hukum kepada konsumen oleh negara. Dalam rangka mengembangkan upaya perlindungan konsumen, maka dibentuklah Badan Perlindungan Konsumen Nasional dan Badan Penyelesaian Sengketa Konsumen Perlindungan konsumen oleh negara berkaitan dengan periklanan, Undang- Undang Perlindungan Konsumen memuat pengaturannya bersama dengan perbuatan-perbuatan yang dilarang bagi pelaku usaha, dalam Pasal 9, 10, 12, 13, 17 dan Pasal 20 Undang-Undang Perlindungan Konsumen. Bentuk lain perlindungan konsumen oleh negara dari informasi iklan barang dan jasa yang menyebabkan kekeliruan dapat dilihat dalam putusan hakim yang adil serta menerapkan asas-asas dan aturan hukum sebagaimana mestinya.Perlindungan konsumen oleh Negara selain membuat kebijakan yang berwujud dalam bentuk peraturan perundang-undangan, didalam Undang-undang Perlindungan Konsumen secara umum negara mengemban tugas pembinaan dan pengawasan penyelengaraan perlindungan konsumen, termasuk tugas pembinaan dan pengawasan kegiatan periklanan. Serta Pertanggungjawaban Pelaku Usaha Terhadap Penyampaian Informasi IkIan yang Menyebabkan Kekeliruan.

\section{Saran}

1. Demi terciptanya keseimbangan dalam transaksi konsumen dengan produsen melalui Periklanan diharapkan dengan adanya peraturan perundang-undangan tentang Periklanan.

2. Didalam Pasal 62 Undang-Undang Perlindungan Konsumen terdapat sanksi pidana, alangkah baiknya apabila bentuk ancaman pidana yang dijatuhkan kepada pelaku pelanggaran ketentuan periklanan dapat berupa pidana penjara dan bukan pidana denda, agar sanksi pidana yang dijatuhkan tersebut benar benar menimbulkan efek jera serta meningkatkan kepatuhan pelaku usaha terhadap norma-norma Undang-Undang Perlindungan Konsumen.

\section{DAFTAR PUSTAKA}

\section{Buku}

Dedi Harianto, Perlindungan Hukum Bagi Konsumen Terhadap Iklan Yang Menyesatkan, Bogor, Ghalia Indonesia, 2010

Husni Ayawali, Neni Sri Imaniyati (ed), Hukum Perlindungan Konsumen, Mandar Maju, Ba ndun $g, 2000$

Maria m Darus Badrusza man. 1986. Perlindungan Konsumen Dilihat dari Sudut PerjanjianBaku.Jakarta: Bina Cipta

Yusuf shofie,4,"system tanggung jawab dalam periklanan", hukum dan pembangunan,no.2 tahun xxvi,april 1996

Wahyu Aji Chalifar, 2018, Konsumen Dan Iklan : Studi Tentang Iklan Yang Menyesatkan Di Facebook Twitter Dan Instagram, Surakarta

\section{Artikel Jurnal}


Agus Brotosusilo, "Hak-hak Produsen dalam Hukum Perlindungan Konsumen Majalah HUKUM dan PEM BANGUNAN, edisi Oktober. Jakarta: Fakultas Huku m UI, 1992.

Mabarroh Azizah, 2013, Etika Perilaku Periklanan Dalam Bisnis Islam, Jurnal Ekonomi Syariah Indonesia vol III, No 1 Juni 2013/1434 H

Ibnu Subarkah, L. H. (2017). Law Enforcement to Offenders' Rights Based on Contempt of Court. Yustisia.

\section{Website}

Haris Fadhil. 2018. Heboh Kental Manis. Diambil April 5, 2021, dari https://news.detik.com/berita/4098935/heboh-kental-manis

\section{Penelitian Tugas Akhir}

Adi Handono, Perlindungan Hukum Bagi Konsumen Terhadap Informasi Iklan Barang Dan Jasa Yang Menyesatkan, Tesis pada Program Magister Ilmu Hukum Universitas Jember, Jember, 2011

Ahmad Zazili, Perlindungan Huk um Terhadap Penumpang Pada Transportasi Udara Niaga Berjadwal Nasional, Tesis pada Program Magister Ilmu Huku m Unive rsitas Diponegoro, Semarang, 2008

A.z nasution,4,kedudukan hukum konsumen terhadap iklan, makalah yang disampaikan pada seminar hukum "perlindungan hukum bagi konsumen dari dampak iklan",di selenggarakan senat mahasiswa fakultas hukum universitas isalam as syafi'iyah, Jakarta, 6 mei 1995, hal 12.

Indra santoso.Tinjauan yuridis terhadap tanggung jawab pelaku usaha dikaitkan dengan iklan-iklan yang menyesatkan konsumen.Tesis pada Program Mag ister Hukum Universitas Indonesia. Jakarta,

Zulkarnaen, Perlindungan Hukum Terhadap Konsumen Barang-Barang Elektronik, Tesis pada Program Magister Ilmu Hukum Universitas Diponegoro, Semarang, 2008

\section{Peraturan Perundang-undangan}

Pasal 1 angka 6 Undang-undang Nomor 8 Tahun 1999 Tentang Perlindungan Konsumen.

Pasal 1 angka 2 Undang-undang No. 8 tahun 1999 Tentang Perlindungan Konsumen

UU No 8 tahun 1999 tentang perlindungan konsumen dibedakan antara pelaku usaha sebagaimana terdapat dalam pasal 1 angka 3 UU no 8 tahun 1999 tentang perlindungan konsumen

\section{Putusan Pengadilan}

S.P.de Boer v.N.V.Good Year Sumatra Plantations Ltd. Cs., Putusan Mahkamah Agung No. 27 K/SIP/1972,tanggal 5 juli 1972

Pasal 13 uu no 40 tahun 1999 tentang pers (lembaga Negara republik Indonesia no.166 tahun 1999) 
